diagnostics and therapies, local availability of medical, surgical and radiological treatment as well as a stable online video connection. The iMDTB has a significant impact not only on multidisciplinarity of cancer management in the cooperating institutions but also on social values and education of the participants.

Disclosures None.

\section{CENTRE OF HEREDITARY BREAST AND OVARIAN CANCER AT CHARITÉ - WHO PRESENTS FOR COUNSELING AND WHY?}

Malina Helms, Nanette Kalmbach, Caroline Neeb, Julia Kussmaul, Dorothee Speiser. Charité - Universitätsmedizin Berlin

\subsection{6/ijgc-2020-ESG0.192}

Introduction/Background Since the discovery of the BRCAgenes the knowledge about genetic risk factors for breast and ovarian cancer has multiplied. About $5-10 \%$ of all breast cancers and $15-20 \%$ of all ovarian cancers are caused by pathogenic mutations in different risk genes. Therefore, the Centre of Hereditary Breast and Ovarian Cancer at Charité offers as one of 20 centres in Germany genetic counseling. The extensive data of the counselees was now evaluated for the first time. The aim of this study was to ease the preparation for counseling sessions and gather information for more individualized counseling.

Methodology Data from 2531 counselees at the Charite-Centre from 2016 and 2017 were evaluated retrospectively. Special emphasis was laid on sociodemographic data and the results of genetic testing. Finally, the mutation frequencies were analyzed in different subgroups.

Results The 2531 counselees were almost exclusively female (n $=2493 ; 98.5 \%), 42.9$ years old on average and came to the centre for the first time ( $\mathrm{n}=2198 ; 86.8 \%) .2287$ (90.4\%) counselees met the inclusion criteria for genetic testing. Of these, $863(37.7 \%)$ were already diagnosed with breast or ovarian cancer. $1367(59.8 \%)$ were genetically tested, 918 $(67,2 \%)$ as index patients and $449(32,8 \%)$ predictively. Mutations were detected in $545(39.9 \%)$ tested persons. Most mutations were detected in BRCA1, BRCA2, CHEK2 and ATM. The highest mutation frequency was found among persons from families with both breast and ovarian cancer and in

Abstract 139 Table 1 Cancer specifics and age at first diagnosis

\begin{tabular}{|c|r|r|}
\hline & $\begin{array}{c}\text { Counselees } \\
\text { inclusion criteria }\end{array}$ \\
\hline n=2287 & $(\mathbf{1 0 0 \% )}$ \\
\hline Malignant tumor disease & 1387 & $(60,6 \%)$ \\
\hline No tumor & 787 & $(34,4 \%)$ \\
\hline Breast cancer & 562 & $(24,6 \%)$ \\
\hline ER/PgR/HER2-positive & 180 & $(7,9 \%)$ \\
\hline triple-negative & 41 & $(1,8 \%)$ \\
\hline DCIS & 4 & $(0,2 \%)$ \\
\hline male breast cancer & 76 & $(3,3 \%)$ \\
\hline Ovarian cancer & 37 & $(1,6 \%)$ \\
\hline Other malignant tumor disease & 44,4 & $(24-83$ years) \\
\hline Age at first diagnosis, mean in years & 50,8 & $(17-75$ years $)$ \\
\hline Breast cancer & & \\
\hline Ovarian cancer &
\end{tabular}

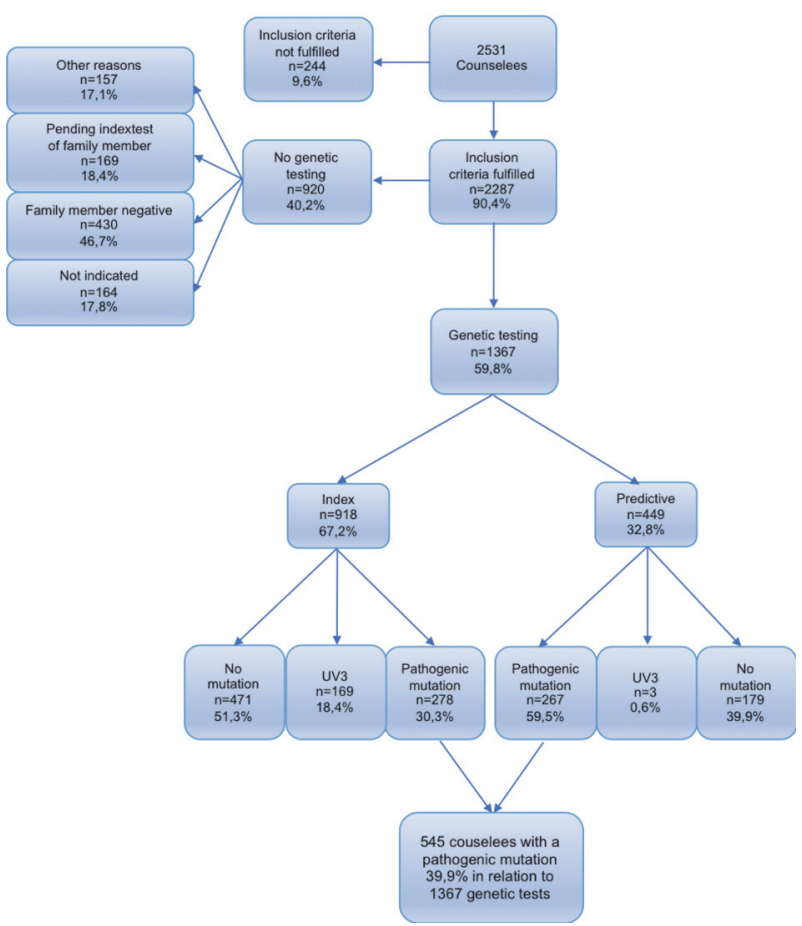

Abstract 139 Figure 1 Flow chart of the results of the genetic testing

patients with TNBC. A significant correlation was found between mutation frequency in TNBC and age at first diagnosis (figure 1).

Conclusion In summary, the collective of counselees at the Charité- Center was described for the first time. The results provide doctors with a comprehensive overview of the counselees, enabling by that an even more individualized counseling and more focused preparation for the consultation.

The findings contribute to maintaining the high quality of the genetic counseling at the Centre for Familial Breast and Ovarian Cancer at the Charité (table 1).

Disclosures No conflict of interest.

\section{WHEN MDT INTERDISCIPLINARITY ENHANCES STRINGENCY AND PROFESSIONAL QUALITY; AN ANALYSIS OF MULTI-DISCIPLINARY TEAM CONFERENCES}

${ }^{1}$ Sigrid Kasper Fog, 'Lene Lundvall, ${ }^{2}$ Rikke Hagemann-Madsen, ${ }^{3}$ Pernille Dehn, ${ }^{4}$ Jens Hillingsø, ${ }^{5}$ Lone Nørgård Petersen, ${ }^{6}$ Jon Asmussen, ${ }^{7}$ Michael Borre, ${ }^{8}$ Torben Riis Rasmussen, ${ }^{9}$ Merete Watt Boolsen. ${ }^{1}$ Copenhagen University Hospital; Gynecological Department; ${ }^{2}$ Lillebaelt Hospital; Department of Pathology; ${ }^{3}$ University Hospital of Copenhagen; Gynecological Department; ${ }^{4}$ University Hospital of Copenhagen; Surgical Gastroenterological Department C, Abdominal Center; ${ }^{5}$ University Hospital of Copenhagen; Department of Oncology; ${ }^{6}$ University Hospital of Odense; Radiology Department; ${ }^{7}$ University Hospital of Aarhus; Urology Department; ${ }^{8}$ University Hospital of Aarhus; Pulmonary Medicine Department; ${ }^{9}$ University of Copenhagen; Department of Political Science

\subsection{6/ijgc-2020-ESGO.193}

Introduction/Background In 2016 the Danish Multidisciplinary Cancer Group's (DMCG) national Multidisciplinary Team (MDT) working committee established recommended quality standards in Danish healthcare.

This current study investigates the status of implementation of the guideline published in 2016 amongst the clinicians who 